\title{
THE TALL-HERB AND TALL-GRASS PLANT COMMUNITIES OF THE CLASS MULGEDIO- ACONITETEA IN THE SUBALPINE BELT OF THE KRIVÁNSKA MALÁ FATRA MTS (SLOVAKIA)
}

\author{
Ivana ŠIBÍKOVÁ*, Jozef ŠIBÍK* \& Ivan JAROLÍMEK*
}

\begin{abstract}
The following paper reports the results of phytosociological research of tall-herb and tall-herb plant communities within the class Mulgedio-Aconitetea in the subalpine belt of the Krivánska Malá Fatra Mts. The data set of 209 relevés was sampled and analysed using numerical classification and ordination. Major ecological gradients were interpreted using Ellenberg's indicator values and the Shannon-Wiener diversity index. Ten associations within five alliances were distinguished and characterised: Aconitetum firmi, Digitali ambiguae-Calamagrostietum arundinaceae, Helianthemo grandiflorae-Calamagrostietum arundinaceae, Potentillo aurei-Calamagrostietum arundinaceae, Allio victorialis-Calamagrostietum villosae, Festucetum carpaticae, Adenostylo alliariae-Athyrietum alpestris, Aconito firmi-Adenostyletum alliariae, Geranio robertiani-Delphinietum elati and Aconito firmi-Rumicetum alpini. Relationships between the floristic composition of the communities and environmental variables were analysed by canonical correspondence analysis.

Key words: alpine vegetation, classification, ordination, phytosociology, tall-herb plant communities.

Izvleček

V članku so prikazani rezultati fitocenološke raziskave rastlinskih združb visokih steblik in trav razreda Mulgedio-Aconitetea v subalpinskem pasu gorovja Krivánska Malá Fatra. Podatkovni niz sestavlja 209 popisov, ki smo jih analizirali z numerično klasifikacijo in ordinacijo. Glavne ekološke gradiente smo interpretirali z Ellenbergovimi indikacijskimi vrednostmi in Shannon-Wienerjevim indeksom diverzitete. Ločili smo deset asociacij znotraj petih zvez in jih opisali: Aconitetum firmi, Digitali ambiguae-Calamagrostietum arundinaceae, Helianthemo grandiflorae-Calamagrostietum arundinaceae, Potentillo aurei-Calamagrostietum arundinaceae, Allio victorialis-Calamagrostietum villosae, Festucetum carpaticae, Adenostylo alliariae-Athyrietum alpestris, Aconito firmi-Adenostyletum alliariae, Geranio robertiani-Delphinietum elati in Aconito firmi-Rumicetum alpini. Povezavo med vrstno sestavo rastlinskih združb in rastiščnimi dejavniki smo analizirali s kanonično korespondenčno analizo.

Ključne besede: alpinska vegetacija, klasifikacija, ordinacija, fitocenologija, rastlinske združbe visokih steblik.
\end{abstract}

\section{INTRODUCTION}

The class Mulgedio-Aconitetea Hadač et Klika in Klika 1948 comprises tall-herb and tall-grass communities in the altimontane to alpine belt found mainly on mesophilous habitats along mountain streams and on sheltered habitats with a sufficient supply of moisture and nutrients and with thick snow cover in winter. Near the tree line, they occur predomi- nantly on edaphically or mechanically conditioned natural (primary) tree-less places (talus cones, avalanche glens). These relatively species-rich communities are conspicuously multicoloured during the flowering period. In large depressions or small cirques, on convex or concave slopes on marl limestone, and more rarely in moist rocky glens among dwarf-pine stands, they form vegetation complexes with the subalpine deciduous shrub communities

* Slovak Academy of Sciences, Institute of Botany, Dúbravská cesta 14, SK-845 23 Bratislava, Slovakia.

E-mail: ivana.sibikova@savba.sk,jozef.sibik@savba.sk, ivan.jarolimek@savba.sk 
of the class Betulo carpaticae-Alnetea viridis Rejmánek in Huml et al. 1979 (Kliment et al. 2007a).

Although the National Park Malá Fatra Mts covers an area of only $226.3 \mathrm{~km}^{2}$, it is very diverse and miscellaneous. Even though the highest peak (Mt. Velký Kriváň) reaches only 1,709 m a. s. l., several plant communities typical for an alpine vegetation belt occur there. Many various vegetation types are spread on such a small area in mosaics along the altitudinal gradient and according to geological bedrock, orientation and relief.

The species diversity and the uniqueness of the regional flora is a result of specific evolution of vegetation during the postglacial era, as well as during the last centuries, conditioned by Walachian colonisation (cf. Janík 1971, Plesník 1955).

\section{METHODS}

The data set of 209 phytosociological relevés was used for the analysis: 143 relevés were sampled by the authors and 66 relevés were excerpted from Slovak National Vegetation Database (http://ibot. sav.sk/cdf; see Šibíková et al. 2009). All relevés were gained following standard procedures of the Zürich-Montpellier School (Braun-Blanquet 1964, Westhoff \& van den Maarel 1978), mostly using the modified 9-degree Braun-Blanquet sampling scale (Barkman et al. 1964), and older relevés by Bělohlávková using the 7-degree Old Braun-Blanquet sampling scale (Braun-Blanquet 1964) and stored in a TURBOVEG database (Hennekens \& Schaminée 2001). Before performing the numerical synthesis, the cryptogam layer was excluded (due to the uneven determination of cryptogams in individual relevés), as well as the taxa determined only to genus level. Several taxa were included into the higher or broadly considered taxonomical units: Achillea millefolium agg. (subsp. alpestris, A. setacea), Alchemilla spec. div. (A. crinita, A. monticola, A. vulgaris, A. xanthochlora), Anthoxanthum alpinum (A. odoratum), Arabis hirsuta agg. (A. sagittata), Bupleurum longifolium (subsp. vapincense), Cardaminopsis arenosa agg. (C. borbasii, C. borbasii subsp. carpatica), Carex flacca (subsp. flacca), Crepis mollis (subsp. mollis), Dactylis glomerata (subsp. slovenica), Dryopteris dilatata s. 1. (D. carthusiana, D. expansa), Galeobdolon luteum s. 1. (G. montanum), Galium mollugo agg. ( $G$. album), Galium anisophyllon (G. pumilum), Helianthemum grandiflorum s. 1. (subsp. grandiflorum, subsp. obscurum), Heracleum sphondylium (subsp. trachycarpum), Jovibarba globifera (subsp. hirta), Knautia ar- vensis agg. (K. kitaibelii), Leontodon hispidus (subsp. hispidus), Leucanthemum vulgare agg. (L. margaritae), Lotus corniculatus s. 1. (var. alpicola Beck), Luzula luzuloides (subsp. rubella, subsp. luzuloides), Myosotis scorpioides agg. (M. nemorosa), Pimpinella major (subsp. rhodochlamys), Polygala amara (subsp. brachyptera), Senecio nemorensis agg. (S. hercynicus, S. ovatus), Solidago virgaurea (subsp. minuta), Thymus pulcherrimus (subsp. pulcherrimus, subsp. sudeticus, T. $\times$ pseudocarpaticus), Trifolium pratense (subsp. pratense, subsp. kotulae). The subspecies in the tables (given without the species name) are marked with asterisks (*).

Numerical classification was performed using the program PC-ORD (McCune \& Mefford 1999). Ward's method with the Euclidean distance similarity coefficient was used. To decrease the difference between close values of higher absolute cover (cf. Lepš \& Šmilauer 2000, Herben \& Münzbergová 2003), data were transformed by square root transformation. The diagnostic taxa were calculated using a statistically defined coefficient of fidelity (phi coefficient, $\Phi$; cf. Chytrý et al. 2002) for particular groups of relevés, created by the cluster analysis of all 209 relevés, which represent individual syntaxa. Since the fidelity calculations for individual clusters are dependent on the number of relevés in the clusters, the standardisation of the size of all site groups was performed (with the target group being of the same size as the others; cf. Tichý \& Chytrý, 2006). To reduce the effect of coincidentally occurring species in the data set, Fisher's exact test was used (cf. Chytrý et al. 2002, Chytrý 2007) with the significance level $\mathrm{p}<0.001$.

These diagnostic groups of species have local applicability, since they reflect the results of the analysis of data gained only from the area of the Krivánska Malá Fatra Mts (cf. Šibíková 2006). Within them, the diagnostic species (fidelity value 0.30 ), constant species (frequency $60 \%$ ) and dominant species (cover $>50 \%$ ) were determined, corresponding to the results of numerical analysis of tall-grass and tall-herb plant communities of the Krivánska Malá Fatra Mts (cf. Šibíková 2006). Diagnostic species for individual communities of the Krivánska Malá Fatra Mts are discussed and compared with the results of huge syntaxonomical revision of high mountain vegetation from the area of Western Carpathians (Kliment et al. 2007a).

The synoptic table was generated in JUICE 6.4, the software for analysis and classification of ecological data (Tichý 2002) and finally arranged in the programme Microsoft Word. In the tables with 
few relevés $(<5)$ the frequency was replaced by the values of presence $(P)$ of individual taxa. The synoptic table encompasses only those syntaxa which include more than three phytosociological relevés. Syntaxa supported by less than three relevés are stated in the text together with the citation of a recent paper, which deals with the syntaxon, or together with the relevés.

The syntaxonomical classification of the vegetation follows the results of broader syntaxonomical revisions of the class Mulgedio-Aconitetea within the Western Carpathians (Kliment \& Jarolímek 2003, Kliment et al. 2004, 2007a). The results of the regional synthesis from the Krivánska Malá Fatra Mts were interpreted in accord with the results of adduced broader revisions, whilst the regional particularities and differences were highlighted.

The main gradients in species composition of tall-herb and tall-grass plant communities in the Krivánska Malá Fatra Mts were analysed by detrended correspondence analysis (DCA) in the CANOCO 4.5 program package (ter Braak \& Šmilauer 2002). For the interpretation from the ecological point of view, not only the floristic composition, but also the Ellenberg's indicator values (Ellenberg et al. 1992) and the Shannon-Wiener index of diversity (Hill 1973, Tichý \& Holt 2006) were used as supplementary data. However, both data sets were analysed as non-dependent variables to avoid tautological argumentation, i.e. the problem of "multiple testing” (cf. Herben \& Münzbergová 2003). Canonical correspondence analysis (CCA) was used to analyse the relations of the species composition of the vegetation and the environmental variables - altitude, slope, $\mathrm{pH}\left(\mathrm{H}_{2} \mathrm{O}\right)$, cover of cryptogam layer and geological bedrock (calcite, granite, quartzite, marl and sandstone). Only the relevés with all chosen environmental variables available (57 relevés) were analysed by CCA.

The geological bedrock was identified directly in the field and checked in Regional Geological Maps of the Slovak Republic (Haško \& Polák 1980). The nomenclature of the taxa generally follows the Checklist by Marhold \& Hindák (1998), except for these taxa: Carex sempervirens subsp. tatrorum (Zapał.) Pawł., Hieracium valdepilosum Vill., Lotus corniculatus var. alpicola Beck. The names of syntaxa and lists of their diagnostic taxa follow the outline of Kliment \& Jarolímek (1995), Valachovič et al. (1995), Valachovič et al. (2001), Šibík et al. (2005) and Kliment et al. (2007b). Abbreviations are used in the text as follows: agg. = aggregate taxa, cf. = compare, spec. div. $=$ various species, $r .=$ relevé .
Abbreviations of the syntaxa names used in table are: aa Adenostylion alliariae, ar Arabidion alpinae, ca Calamagrostion arundinaceae, $\mathbf{c f}$ Caricion firmae, $\mathbf{c r}$ Calamagrostion variae, $\mathbf{c v}$ Calamagrostion villosae, de Delphinenion elati, fc Festucion carpaticae, pm Pinion mugo, po Petasition officinalis, pt Papaverion tatrici, sa Astero alpini-Seslerion calcariae, ss Salicion silesiacae, st Seslerion tatrae, tf Trisetion fusci, $\mathbf{C v}$ Calamagrostietalia villosae, $\mathbf{G p}$ Galio-Parietarietalia officinalis, Mc Montio-Cardaminetalia, Pc Potentilletalia caulescentis, AT Asplenietea trichomanis, ES Elyno-Seslerietea, LV Loiseleurio-Vaccinietea, MC Montio-Cardaminetea, MU Mulgedio-Aconitetea, NS Nardetea strictae, TR Thlaspietea rotundifolii.

Abbreviations of the taxa names used in figures (Figure 5 \& 7) are: Acetarif-Acetosa arifolia, Achimila - Achillea millefolium subsp. alpestris, Aconfirm - Aconitum firmum subsp. moravicum, Adenalli-Adenostyles alliariae, Alchsp.d - Alchemilla spec. div., Allivict - Allium victorialis, Astrmajo - Astrantia major, Athydist - Athyrium distentifolium, Avenflex - Avenella flexuosa, Bistmajo - Bistorta major, Calaarun - Calamagrostis arundinacea, Calavari - Calamagrostis varia, Calavill - Calamagrostis villosa, Campserr-Campanula serrata, Careflac - Carex flacca, Caresemt - Carex *tatrorum, Chaehirs - Chaerophyllum hirsutum, Cicealpi-Cicerbita alpina, Cortmatt - Cortusa matthioli, Creppalu-Crepis paludosa, Cyanmoll - Cyanus mollis, Dactglom - Dactylis glomerata, Daphmeze - Daphne mezereum, Delpoxys - Delphinium oxysepalum, Desccesp - Deschampsia cespitosa, Doroaust - Doronicum austriacum, Epilalpe - Epilobium alpestre, Epilangu - Epilobium angustifolium, Festcarp - Festuca carpatica, Gentascl-Gentiana asclepiadea, Gerasylv - Geranium sylvaticum, Geumriva - Geum rivale, Heraspho - Heracleum sphondylium, Homoalpi - Homogyne alpina, Hypemacu - Hypericum maculatum, Knauarve - Knautia arvensis agg., Ligumuta - Ligusticum mutellina, Luzuluzo - Luzula luzuloides, Luzusylv - Luzula sylvatica, Milieffu - Milium effusum, Myosnemo - Myosotis nemorosa, Myossylv - Myosotis sylvatica, Pimpmajo - Pimpinella major, Poa chai-Poa chaixii, Primelat-Primula elatior, Rubuidae - Rubus idaeus, Rumealpi - Rumex alpinus, Saxirotu - Saxifraga rotundifolia, Seneherc - Senecio hercynicus, Senenemo - Senecio nemorensis agg., Senesuba - Senecio subalpinus, Sesltatr - Sesleria tatrae, Siledioi - Silene dioica, Soldcarp - Soldanella carpatica, Stelnemo - Stellaria nemorum, Swerpere - Swertia perennis, Thalaqui - Thalictrum aquilegiifolium, Trisflav - Trisetum flavescens, Vaccmyrt - Vaccinium myrtillus, Valetrip - Valeriana tripteris, Veralobe - Veratrum *lobelianum, Violbifl - Viola biflora. 


\section{STUDY AREA}

Malá Fatra National Park lies in the northwest part of Slovakia (Figure 1). The geographical coordinates range within $49^{\circ} 08^{\prime} 00^{\prime \prime}-49^{\circ} 19^{\prime} 30^{\prime \prime}$ of the latitudes and $18^{\circ} 50^{\prime} 30^{\prime \prime}-19^{\circ} 14^{\prime} 45^{\prime \prime}$ of the longitude (Pagáč et al. 1983). The total area of the national

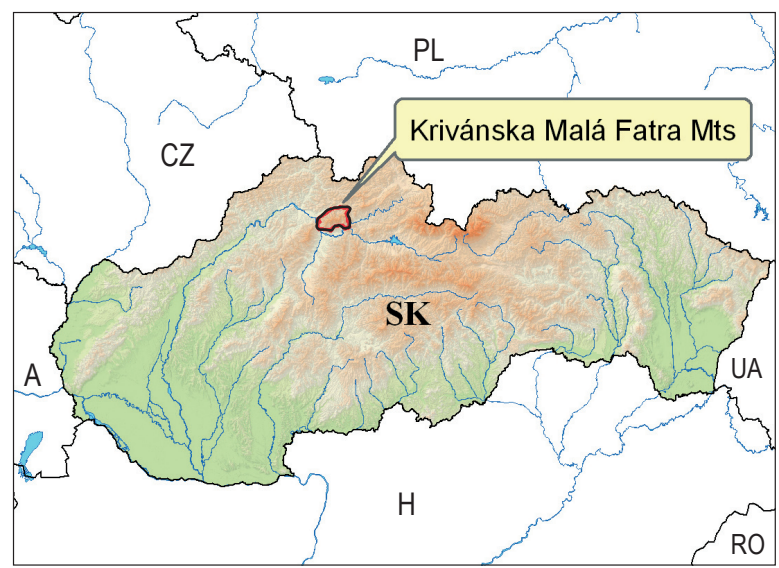

Figure 1: Map of the studied area (Krivánska Malá Fatra Mts) located within Slovakia and Europe.

Slika 1: Karta raziskovanega območja (gorovje Krivánska Malá Fatra) na Slovaškem in položaj v Evropi. park covers $226.30 \mathrm{~km}^{2}$. The longest distance from west to east is $35 \mathrm{~km}$ and from north to south 20 $\mathrm{km}$. The highest peak (1,709 m a. s. 1.) is Mt. Velký Kriván (http://www.sopsr.sk/malafatra).

According to the phytogeographical division of Slovakia (Bertová 1984), the area belongs to the West Carpathian's flora region (Carpaticum occidentale) and to the high Central Carpathian's flora district (Eucarpaticum). The geomorphological character of Malá Fatra Mts was formed during the postglacial era. It is marked out by the great altitudinal differences, steep slopes and hence by the relatively small mass of the mountains (Ložek 1972). These facts, together with the specific position within high mountain ranges of the central Carpathians (Malá Fatra Mts is the most northwestern mountain range and hence the first windbreaking barrier to strong north-western winds), miscellaneous geological bedrock and landscape heterogeneity contribute to an exceptional variability of natural ecosystems in the area.

The map of the study area with depicted localities of individual recent phytosociological relevés used in this work is shown in Figure 2.

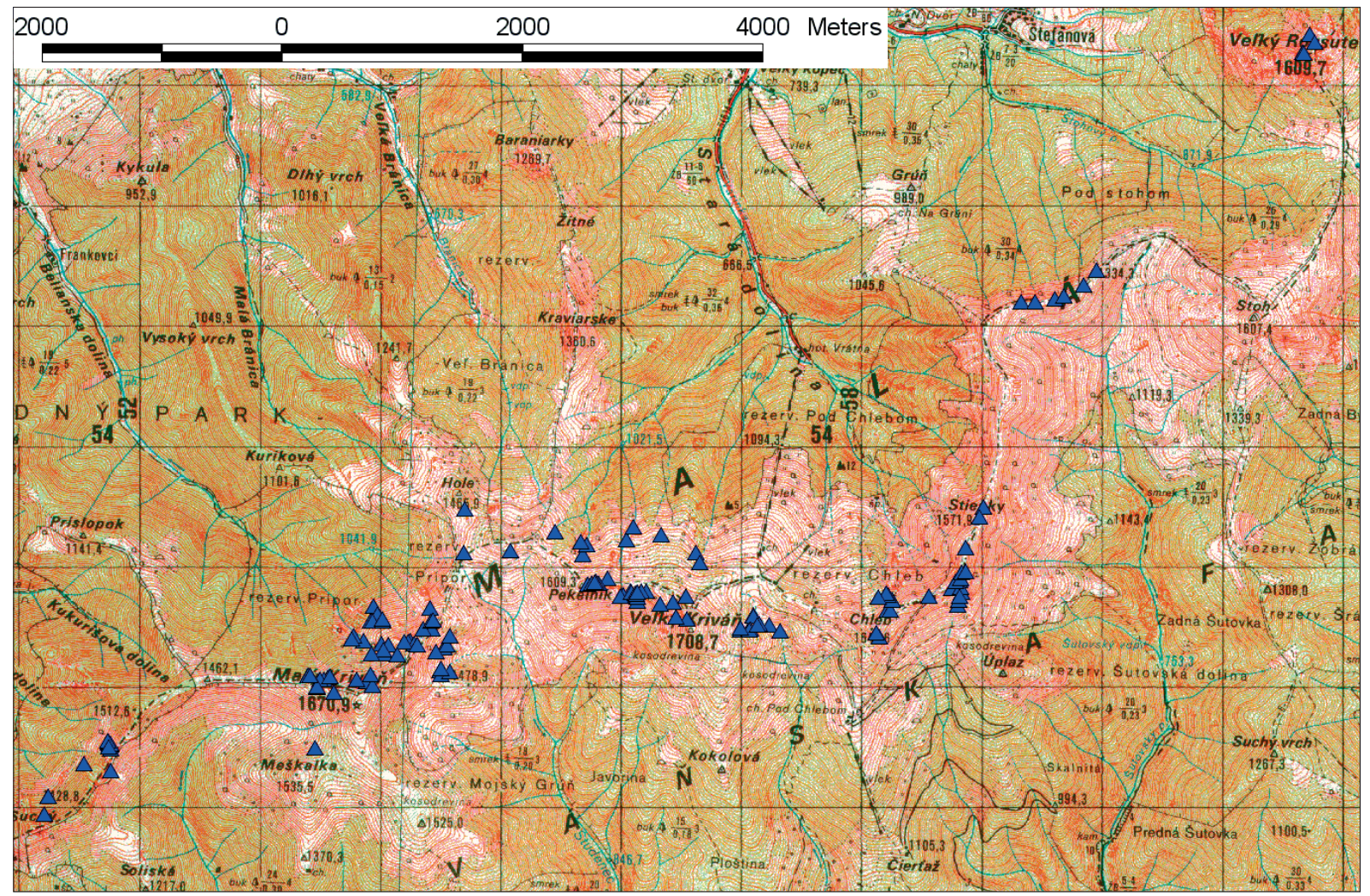

Figure 2: Map of the studied area (Krivánska Malá Fatra Mts) and the localities of individual recent phytosociological relevés. Slika 2: Karta raziskovanega območja (gorovje Krivánska Malá Fatra) in kraji posameznih (recentnih) fitocenoloških popisov. 


\section{RESULTS AND DISCUSSION}

\section{Classification}

Based on the broader syntaxonomical revisions of the class Mulgedio-Aconitetea within the whole area of the Western Carpathians (Kliment \& Jarolímek 2003, Kliment et al. 2004, 2007a), we decided to accept this concept of the class, although it differs in some aspects from the phytosociological systems published in neighbouring countries (cf. Pott 1995, Karner \& Mucina 1993, Theurillat et al. 1995).

In the interpretation of the dendrogram (Figure 3), the fifth highest level of dissimilarity was taken into account. Individual clusters in the dendrogram represent particular, floristically well differentiated vegetation units, clearly interpretable also on the level of higher syntaxa. Cluster C, which represents the alliance Festucion carpaticae and its only association Festucetum carpaticae, was formed on the highest level of dissimilarity. The uniqueness of this association caused in the past the disunited classification into higher syntaxa, for example into the alliances Seslerion coerulae (cf. Braun-Blanquet 1930) or Seslerion tatrae (cf. Hadač et al. 1969, Dúbravcová \& Hajdúk 1986). The second cluster represents the alliance Calamagrostion arundinaceae (Figure 3, cluster B). Cluster A is identified as the order Adenostyletalia alliariae and the alliance Adenostylion alliariae. Within this cluster, a group of relevés was formed on the highest level of dissimilarity, identified as the sub-alliance Adenos-

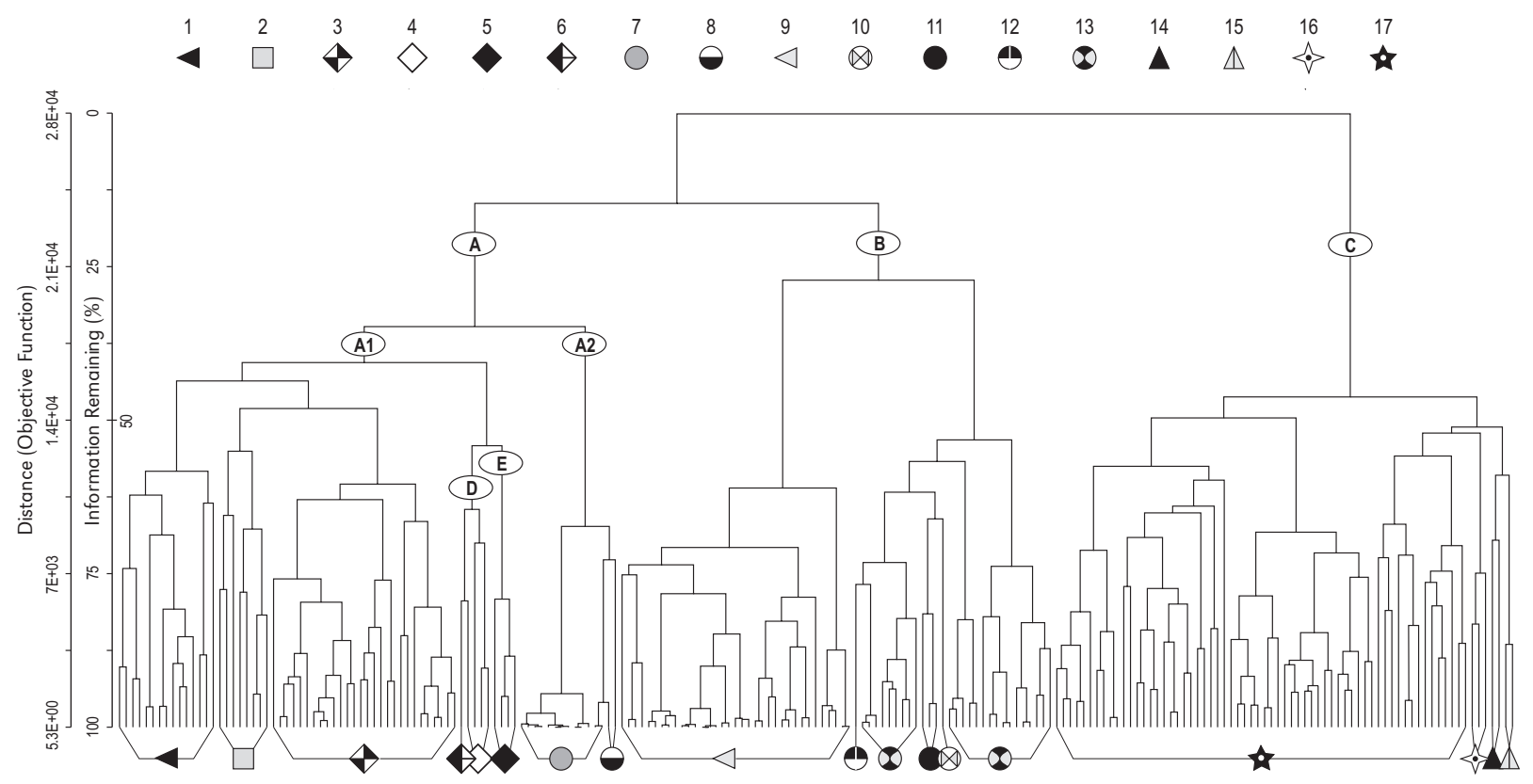

Figure 3: Dendrogram of the numerical classification of the tall-herb plant communities of the class Mulgedio-Aconitetea in the area of Krivánska Malá Fatra Mts. Parameters used: Ward's method, Euclidean distance, Square root transformation. Symbols used: 1., 2., 3. Aconito firmi-Adenostyletum alliariae; 4. Aconitetum firmi; 5. Aconito firmi-Rumicetum alpini; 6. Aconito firmi-Rumicetum alpini, floating phytocoenose towards the association Aconitetum firmi; 7 . Adenostylo alliariaeAthyrietum alpestris; 8. Phytocoenoses dominated by Athyrium distentifolium, floating towards the association Aconito firmiAdenostyletum alliariae; 9. Allio victorialis-Calamagrostietum villosae; 10. Digitali ambiguae-Calamagrostietum arundinaceae, 11. Helianthemo grandiflorae-Calamagrostietum arundinaceae; 12. Helianthemo grandiflorae-Calamagrostietum arundinaceae, floating phytocoenose towards the association Potentillo aurei-Calamagrostietum arundinaceae; 13. Potentillo aurei-Calamagrostietum arundinaceae; 14. Geranio robertiani-Delphinietum elati; 15., 16., 17. Festucetum carpaticae.

Slika 3: Dendrogram numerične klasifikacije rastlinskih združb visokih steblik razreda Mulgedio-Aconitetea v območju gorovja Krivánska Malá Fatra. Uporabljeni parametri: Wardova metoda, Evklidska razdalja, transformacija s kvadratnim korenom. Uporabljeni simboli: 1., 2., 3. Aconito firmi-Adenostyletum alliariae; 4. Aconitetum firmi; 5. Aconito firmi-Rumicetum alpini; 6. Aconito firmi-Rumicetum alpini, floating phytocoenose towards the association Aconitetum firmi; 7. Adenostylo alliariae-Athyrietum alpestris; 8. Phytocoenoses dominated by Athyrium distentifolium, floating towards the association Aconito firmi-Adenostyletum alliariae; 9. Allio victorialis-Calamagrostietum villosae; 10. Digitali ambiguae-Calamagrostietum arundinaceae, 11. Helianthemo grandiflorae-Calamagrostietum arundinaceae; 12. Helianthemo grandiflorae-Calamagrostietum arundinaceae, floating phytocoenose towards the association Potentillo aurei-Calamagrostietum arundinaceae; 13. Potentillo aurei-Calamagrostietum arundinaceae; 14. Geranio robertiani-Delphinietum elati; 15., 16., 17. Festucetum carpaticae. 
tylenion alliariae (A2). The second sub-alliance Delphinenion elati is represented by cluster A1. Within this cluster, relevés representing the associations Aconitetum firmi (the alliance Trisetion fusci, cluster D) and Aconito firmi-Rumicetum alpini (the alliance Petasition offcinalis, cluster E) were clustered on a lower level of dissimilarity (in comparison with other groups of association rank). This happened due to very similar ecological characteristics of the habitats, and hence close syngenetical relations and floristic composition (the occurrence of hygrophilous to spring species), as well as due to the disproportionately smaller number of relevés in comparison with other associations. Another important factor is the absence of relevés from the most related associations of particular alliances (Trisetion fusci, Petasition officinalis), in latter case also of particular order (Petasito-Chaerophylletalia).

Based on the dendrogram, the synoptic table (Tab. 1) of the associations of the class MulgedioAconitetea from the Krivánska Malá Fatra Mts was created. The diagnostic taxa in the table are ordered according to decreasing fidelity value (phi coefficient $\times 100$; the significance level of the Fisher's exact test is $\mathrm{p}<0.001$ ).

\section{Detrended correspondence analysis}

To display the relations between phytosociological relevés, individual taxa and ecological gradients, the detrended correspondence analysis (DCA) was used. The total variability of the plant communities of Mulgedio-Aconitetea in the Krivánska Malá Fatra Mts is best explained by the first two axes $(12.5 \%)$, the cumulative percentage of variability explained by four axes is $19.7 \%$. The first axis also explains the highest cumulative percentage $(31.4 \%)$ of direct relations between taxa and supplementary environmental variables (in this case Ellenberg's indicator values and Shannon-Wiener's index of diversity). Together with the second axis, they explain $53.1 \%$ of variability (Figs. $4 \& 5$ ).

Figure 5: Detrended correspondence analysis (DCA) ordination diagram of the species. Eigenvalues: 1st axis 0.673 ; 2nd axis 0.514 ; Lengths of gradient: 1 st axis 4.874 ; 2 nd axis 3.643. Ordination scores of the most important species (species weight range is $>4 \%$ ).

Slika 5: Ordinacijski diagram, narejen s kanonično analizo z odstranjenim trendom (DCA) s prikazanimi vrstami. Lastne vrednosti: 1 os $0.673 ; 2$ os 0.514 ; dolžina gradienta: 1 os 4.874; 2 os 3.643. Ordinacijske vrednosti najbolj pomembnih vrst (rang teže vrst $>4 \%$ ).

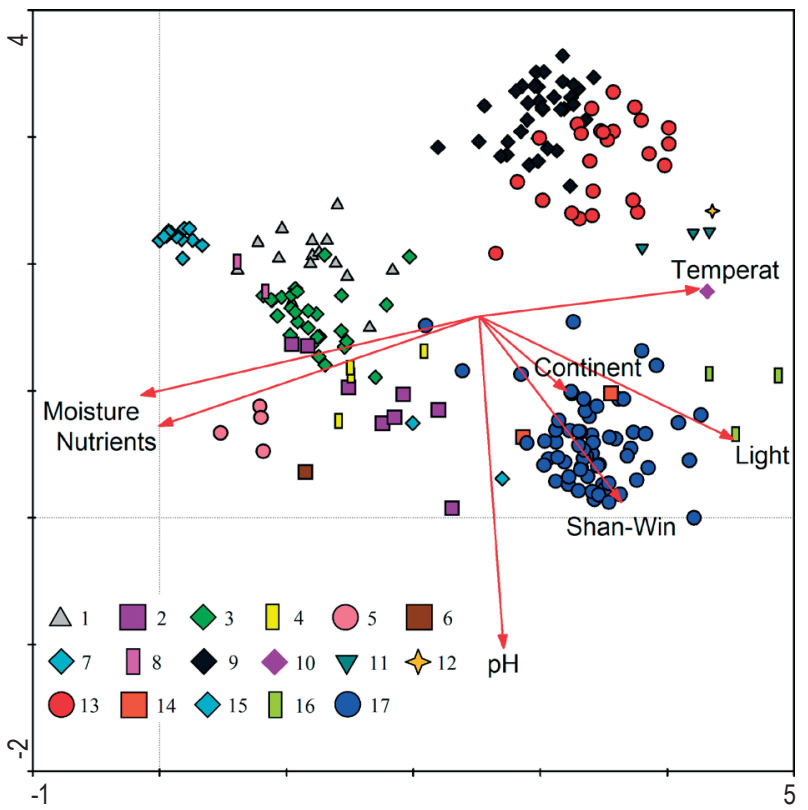

Figure 4: Detrended correspondence analysis (DCA) ordination diagram of 209 relevés from the class MulgedioAconitetea from the area of Krivánska Malá Fatra Mts. Ellenberg's indicator values and Shannon-Wiener's index of diversity were used as supplementary variables. Eigenvalues: 1 st axis 0.673 ; 2 nd axis 0.514 ; Lengths of gradient: 1 st axis 4.874; 2nd axis 3.643. Symbol used: see Fig. 3.

Slika 4: Ordinacijski diagram, narejen s kanonično analizo z odstranjenim trendom (DCA) iz 209 popisov razreda Mulgedio-Aconitetea iz gorovja Krivánska Malá Fatra. Ellenbergove indikacijske vrednosti in Shannon-Wienerjev diverzitetni indeks so uporabljeni kot dodatne variable. Lastne vrednosti: 1 os 0.673 ; 2 os 0.514 ; dolžina gradienta: 1 os $4.874 ; 2$ os 3.643. Pomen simbolov je opisan pod sliko 3 .

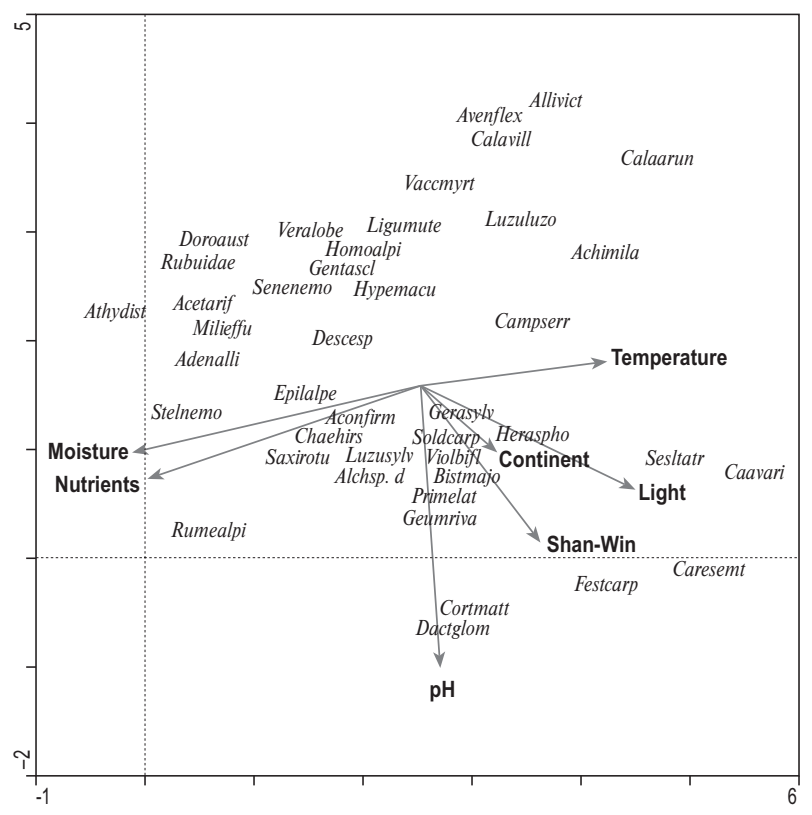


The temperature- as well as light-requirementscorrelates positively with the first (horizontal) axis, the negative correlation shows soil moisture and nutrients (Figs. $4 \& 5$ ). This is why the clusters, which represent some communities of the alliance Calamagrostion arundinaceae are depicted in the right-hand part of the ordination diagram (Figure 4). Those are the tall-grass plant communities, which occur on more dry and warm soils, mostly on slopes exposed to south. The narrow leaves of the grasses do not protect the ground and soil sufficiently enough against the sunshine, as well as they do not prevent the evaporation of soil moisture. The habitat conditions are highlighted by the occurrence of the taxa Sesleria tatrae, Carex *tatrorum, Calamagrostis arundinacea and C. varia (Figure 5). On the left side of the ordination diagram (Figure 4), there can be identified the tall-herb plant communities, typical with the occurrence and dominance of several broad-leaved herbs, e.g. $A d-$ enostyles alliariae or Rumex alpinus (Figure 5), which explains the negative correlation of the group with light-requirements and a positive correlation with soil moisture, hence the broad leaves prevent the sunshine from reaching the lower herb layers, and also protect the soil from soil moisture evaporation. Also the occurrence of these communities is bound mainly to avalanche glens and margins of snow beds, hence moister habitats.

The soil $\mathrm{pH}$ values correlates negatively with the second (vertical) axis (Figure 4). Along this gradient, the cluster representing the association Festucetum carpaticae (alliance Festucion carpaticae) is clearly differentiated against the tall-grass plant communities of the alliance Calamagrostion arundinaceae. Since the phytocoenoses dominated by Festuca carpatica belong in the Krivánska Malá Fatra Mts to the most species-rich plant communities above the timberline, they positively correlate with the Shannon-Wiener index of diversity values. Conversely, the negative correlation is shown by the species-poorest tall-herb plant communities of the Adenostylo alliariae-Athyrietum alpestris (Figure 4). The important factor is the lack of sunshine, due to the formation of very dense, closed phytocoenoses and also very dense litter on soil surface, both of which keep other species from infiltration and catching on in the stands.

Along the gradient of soil moisture and nutrients content, the differences between the stands of the communities Aconito firmi-Rumicetum alpini and Aconitetum firmi can be clearly pointed out. Hence, we consider their classification into two dif- ferent syntaxonomical units as necessary, despite their connection on a lower level of dissimilarity in the dendrogram (Figure 3, other arguments see above).

\section{Canonical correspondence analysis}

The canonical correspondence analysis (CCA) was used to test the relations between the environmental variables and the floristic composition of plant communities of the class Mulgedio-Aconitetea in the Krivánska Malá Fatra Mts. The variability of the floristic composition is best explained by the first two axes $(15.6 \%)$, the cumulative percentage of the explained variability by all four axes is $25.8 \%$. The first axis also explains the highest cumulative percentage $(26.2 \%)$ of direct relations between taxa and environmental variables. Together with the second axis, they explain $45.7 \%$; the cumulative percentage of total variability is $75.7 \%$.

In the ordination diagram (Figure $6 \& 7$ ), the quantitative environmental variables are depicted as the arrows in the direction of increasing values. Categorical variables (geological bedrock) are in the diagram depicted as a point. Similarly, the individual species are shown as points, which represent the apex of the convex curve of their optimal occurrence. The most relevant variables are the cryptogam layer, $\mathrm{pH}$-values and altitude, the latter one being strongly correlated with slope.

The more moist stands of the tall-herb plant communities of the associations Aconito firmi-Adenostyletum alliariae (Figure 6, symbol 3) and Aconito firmi-Rumicetum alpini (Figure 6, symbols $7 \& 8$ ) are clearly differentiated along the gradient of the cryptogam layer against the tall-grass communities, which are characterised by dense and close vegetation, and thick layer of litter on the soil surface, which prevents the development of the cryptogam layer. The relevés representing the association Festucetum carpaticae (Figure 6, symbol 6) are positively correlated with the $\mathrm{pH}$-values, which logically explains the fact, that they are usually bound to calcareous bedrock. A similar relation can be found between the stands of the association Adenostylo alliariae-Athyrietum alpestris (Figure 6, symbol 1), occurring on quartzite bedrock and their negative correlation with $\mathrm{pH}$ - gradient. The phytocoenoses dominated by Calamagrostis villosa (Figure 6, symbol 4) or C. arundinacea (Figure 6, symbol 5) are bound rather to marly bedrock with mostly southerly exposed slopes. 
Figure 6: Canonical correspondence analysis (CCA) ordination diagram of 57 relevés from the class Mulgedio-Ackonitetea from the area of Krivánska Malá Fatra Mts. Eigenvalues: 1 st axis 0.583 ; 2nd axis 0.434 .

1 - Adenostylo-Athyrietum, 2 - Phytocoenoses dominated by Athyrium distentifolium, transition towards the association Aconito-Adenostyletum, 3 - Aconito-Adenostyletum, 4 - Allio-Calamagrostietum villlosae, 5 - relevé with close syngenetic relation to the association HelianthemoCalamagrostietum villosae, 6 - Festucetum carpaticae, 7 - Aconito-Rumicetum alpini, 8 - transitional phytocoenose between the associations Aconito-Rumicetum alpini and Aconitetum firmi.

Slika 6: Ordinacijski diagram narejen s kanonično korespondenčno analizo (CCA) iz 57 popisov razreda Mulgedio-Aconitetea iz gorovja Krivánska Malá Fatra. Lastne vrednosti: 1 os $0.583 ; 2$ os 0.434 .

1 - Adenostylo-Athyrietum, 2 - Združbe $\mathrm{z}$ dominantno vrsto Athyrium distentifolium, prehod k asociaciji Aconito-Adenostyletum, 3 - Aconito-Adenostyletum, 4 - Allio-Calamagrostietum villlosae, 5 - popis singenetsko soroden asociaciji HelianthemoCalamagrostietum villosae, 6 - Festucetum carpaticae, 7 - Aconito-Rumicetum alpini, 8 - prehodna združba med asociacijama Aconito-Rumicetum alpini in Aconitetum firmi.

Figure 7 Canonical correspondence analysis (CCA) ordination diagram of the species. Eigenvalues: 1 st axis 0.583 ; 2 nd axis 0.434 . Ordination scores of the most important species (species weight range is $>$ $6 \%)$.

Slika 7: Ordinacijski diagram, narejen s kanonično korespondenčno analizo (CCA) s prikazanimi vrstami. Lastne vrednosti: 1 os: $0.583 ; 2$ os 0.434 . Ordinacijske vrednosti najbolj pomembnih vrst (rang teže vrst $>6 \%$ ).
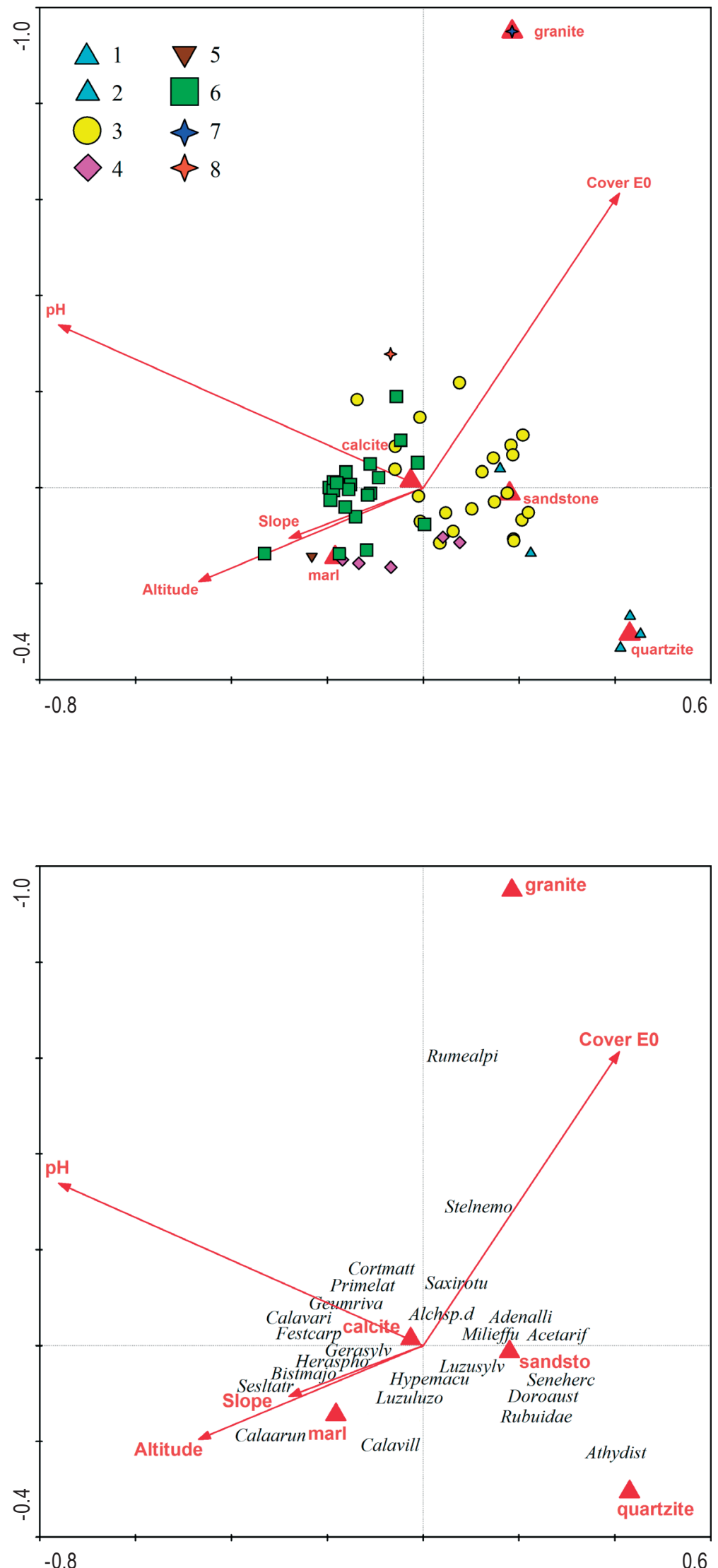
Brief characteristics of the plant communities of the class Mulgedio-Aconitetea occuring in the Krivánska Malá Fatra Mts

\section{Mulgedio-Aconitetea Hadač et Klika in Klika 1948}

Tall-herb communities in the altimontane to alpine belt

Calamagrostietalia villosae Pawłowski et al. 1928

Tall-grass communities of mesophilous high mountain meadows in the subalpine and alpine belt

\section{Trisetion fusci Krajina 1933}

Tall-grass communities on alluviums of mountain streams

Aconitetum firmi Sokołowski in Pawłowski et al. 1928

Tab. 1, column 2

Diagnostic taxa: Caltha* laeta

Constant taxa: Acetosa arifolia, Aconitum *moravicum $^{1}$, Alchemilla spec. div. ${ }^{1}$, Chaerophyllum hirsutum, Crepis paludosa, Deschampsia cespitosa ${ }^{1}$, Geranium sylvaticum, Geum rivale, Heracleum sphondylium, Hypericum maculatum, Senecio subalpinus, Stellaria nemorum, Viola biflora $^{1}$

Dominant taxa: Aconitum *moravicum, Alchemilla spec. div., Caltha *laeta, Stellaria nemorum

${ }^{1}$ species defined by Kliment et al. (2007a) as constant

Floriferous, tall-herb, closed plant communities, whose most characteristic feature during the optimal vegetation season is the occurrence of the abundant to dominant taxon Aconitum * moravicum. Its occurrence is rather rare and bound to moist avalanche glens, with occasionally funnelling torrential water from melted snow or rains. The typical stands occur near mountain streams on granite bedrock. For more details see Šibíková et al. (2007).

\section{Calamagrostion arundinaceae (Luquet 1926) Jeník} 1961

Tall-grass species-rich communities on drier and warmer slopes in the supramontane and subalpine belt

Digitali ambiguae-Calamagrostietum arundinaceae Sillinger 1933

Dominant taxa: Calamagrostis arundinacea
A species-rich, tall-grass plant community of mesophilous high mountain meadows, whose typical floriferousness is given by the occurrence of many species with apparent flowers, such as Aconitum variegatum, Campanula elliptica, Cyanus mollis, or Solidago *minuta. The phytocoenoses occur mainly on the footslopes of scree-cones below the cirques or side slopes of avalanche paths on steep, rocky slopes, where moderately deep, skeletal, densely rooted soils (Kliment 1998) have developed. The stands are usually protected by the thick snow cover in winter - up to $140 \mathrm{~cm}$ (Kliment 1995).

This association, typical with the occurrence of several forest species, is supported from the area of the Krivánska Malá Fatra Mts by the single phytosociological relevé (Šibíková et al. 2008a).

Helianthemo grandiflorae-Calamagrostietum arundinaceae Hadač et al. 1969

Tab. 1, column 6

Diagnostic taxa: Allium *montanum ${ }^{2}$, Asarum europaeum, Dianthus carthusianorum, Fragaria vesca, Rubus saxatilis

Constant taxa: Achillea *alpestris ${ }^{3}$, Calamagrostis arundinacea, Campanula elliptica ${ }^{3}$, C. serrata, Cardaminopsis arenosa agg., Carlina acaulis ${ }^{3}$, Cirsium erisithales $^{3}$, Crepis mollis ${ }^{3}$, Epilobium alpestre, Festuca carpati$\mathrm{ca}^{2}$, Geranium sylvaticum ${ }^{3}$, Heracleum sphondylium, Knautia arvensis agg., Linum extraaxillare ${ }^{3}$, Luzula $*_{r u b e l l a}^{3}$, Potentilla crantzii ${ }^{1}$, Sesleria tatrae ${ }^{2}$, Trisetum flavescens $^{2}$

Dominant taxa: Calamagrostis arundinacea ${ }^{3}$

${ }^{1}$ species defined by Kliment et al. (2007a) as characteristic ${ }^{2}$ species defined by Kliment et al. (2007a) as differential

${ }^{3}$ species defined by Kliment et al. (2007a) as constant

A typically species-rich and diverse tall-grass plant community. The characteristic aspect is formed by vigorous tufts of dominant Calamagrostis arundinacea together with many prominent-flowering tall-forb species. The optimal biotopes of the community are the upper parts of avalanche paths on moderately convex crests on steep $\left(35-45^{\circ}\right)$ and south facing, mostly leeward slopes below the ridge. In the Krivánska Malá Fatra Mts, the stands are confined to a relatively narrow altitudinal range $(1,585-1,600 \mathrm{~m}$ a. s. 1.). For more details see Šibíková et al. (2008a).

Potentillo aurei-Calamagrostietum arundinaceae Kliment 1993

Tab. 1, column 7

Diagnostic taxa: Avenella flexuosa ${ }^{1}$, Avenula planicul- 
mis $^{1}$, Calamagrostis arundinacea, Phyteuma spicatum Constant taxa: Achillea millefolium agg. ${ }^{2}$, Campanula serrata ${ }^{2}$, Geranium sylvaticum, Heracleum sphondylium, Hypericum maculatum ${ }^{2}$, Luzula *rubella ${ }^{2}$, Vaccinium myrtillus ${ }^{2}$

Dominant taxa: Calamagrostis arundinacea ${ }^{2}$

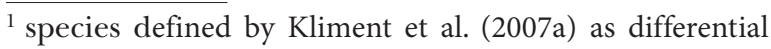
against the communities dominated by Calamagrostis arundinacea.

${ }^{2}$ species defined by Kliment et al. (2007a) as constant

A tall-grass plant community with several welldeveloped herb sub-layers. The phytocoenoses of the association in the Krivánska Malá Fatra Mts are confined to moderately convex crests and the side slopes of avalanche glens of predominantly S-W aspect. The stands are open, sunny and always protected against the strong winds. In winter they are protected by the thick snow cover which, due to the morphology of the terrain accumulates, but in spring melts down quicker than from the stands of other tall-grass communities (Bělohlávková 1980).

Probably the phytocoenoses were originally confined to relatively small areas in canopy gaps of the scarce upper part of the forests, around and above the timberline with the possibility of expanding, e.g. into the avalanche paths (Bělohlávková 1980). For more details see Šibíková et al. (2008a).

\section{Allio victorialis-Calamagrostietum villosae Kliment 1997}

Tab. 1, column 5

Diagnostic taxa: Allium victorialis ${ }^{1}$, Calamagrostis villosa $a^{2}$, Ligusticum mutellina ${ }^{2}$, Solidago * minuta

Constant taxa: Avenella flexuosa ${ }^{3}$, Geranium sylvaticum, Homogyne alpina ${ }^{3}$, Luzula *rubella ${ }^{3}$, Vaccinium myrtillus ${ }^{3}$, Veratrum $*$ lobelianum

Dominant taxa: Avenella flexuosa, Calamagrostis villosa, Vaccinium myrtillus

${ }^{1}$ species defined by Kliment et al. (2007a) as characteristic ${ }^{2}$ species defined by Kliment et al. (2007a) as differential

${ }^{3}$ species defined by Kliment et al. (2007a) as constant

A closed, species-poorer tall-grass plant community dominated by Calamagrostis villosa. The phytocoenoses show the marginal position in transition to the plant communities of the alliance Calamagrostion villosae, which are not present in the Krivánska Malá Fatra Mts. The phytocoenoses of the association are usually situated on leeward, moderately concave slopes, mainly on marl limestone. The suitable biotopes are also shallow terrain depressions or canopy gaps in the dwarf pine shrubs. The altitu- dinal range of the occurrence of sampled localities is $1,350-1,650 \mathrm{~m}$ a. $\mathrm{s}$. 1 . The stands are protected by thick snow cover in winter. For more details see Šibíková et al. (2008a).

Festucion carpaticae Bělohlávková et Fišerová 1989

Tall-grass chionophilous communities in moist craggy glens on carbonates in the higher montane to alpine belt

\section{Festucetum carpaticae Domin 1925}

Tab. 1, column 8

Diagnostic taxa: Astrantia major ${ }^{2}$, Bartsia alpina ${ }^{1}$, Bellidiastrum michelii, Biscutella laevigata, Carex *tatrorum, Cortusa matthioli ${ }^{3}$, Crepis mollis, Festuca carpati$c a^{1}$, Galium anisophyllon, Knautia arvensis agg., Lotus corniculatus s. 1., Phyteuma orbiculare, Primula elatior ${ }^{2}$, Scabiosa lucida, Sesleria tatrae ${ }^{3}$, Soldanella carpatica, Swertia*alpestris, Tithymalus amygdaloides, Valeriana tripteris

Constant taxa: Achillea *alpestris, Alchemilla spec. div. $^{2}$, Campanula serrata, Geranium sylvaticum ${ }^{2}$, Geum rivale, Heracleum sphondylium ${ }^{2}$, Hypericum maculatum $^{2}$, Luzula sylvatica ${ }^{3}$

Dominant taxa: Calamagrostis varia, Carex *flacca, Dactylis * slovenica, Festuca carpatica

${ }^{1}$ species defined by Kliment et al. (2007a) as characteristic 2 species defined by Kliment et al. (2007a) as constant

${ }^{3}$ species defined by Kliment et al. (2007a) as differential for the alliance Festucion carpaticae

A tall-grass plant community, that belongs in the Krivánska Malá Fatra Mts to one of the most speciesrich communities above the timberline. The phytocoenoses are ecologically confined to stabilized soils of calcareous screes, mainly of rendzina type. They occur mostly on northern slopes, in shaded depressions, protected by rocky fences of cirques, in avalanche glens or canopy gaps in the dwarf pine shrubs. The altitudinal range of the studied phytocoenoses was $1,270-1,687 \mathrm{~m}$ a. s. 1 . The stands are profusely watered during the vegetation season by periodical torrential rainwater, which on the other hand prevents the accumulation of humus in the soil. The snow cover on such stands is usually quite deep and long-lasting, it may unexceptionally last until May (cf. Bělohlávková 1980). For more details see Šibíková et al. (2008b).

\section{Adenostyletalia alliariae Br.-Bl. 1930}

Communities of tall herbs and ferns in the subalpine and alpine belt 
Adenostylion alliariae Br.-Bl. 1926

Communities of tall broadleaved herbs and ferns in the subalpine and alpine belt

Adenostylenion alliariae Klika in Klika et Hadač 1944

Communities of tall broadleaved herbs and ferns in the subalpine (to alpine) belt on silicates

\section{Adenostylo alliariae-Athyrietum alpestris (Zlatník 1928) Jeník 1961}

Tab. 1, column 4

Diagnostic taxa: Athyrium distentifolium ${ }^{1}$, Calamagrostis villosa $a^{3}$, Dryopteris dilatata s. 1., Oxalis acetosella ${ }^{2}$, Rubus idaeus ${ }^{2}$

Constant taxa: Acetosa arifolia ${ }^{3}$, Homogyne alpina ${ }^{3}$, Vaccinium myrtillus, Veratrum * lobelianum $^{3}$

Dominant taxa: Athyrium distentifolium

${ }^{1}$ species defined by Kliment et al. (2007a) as characteristic 2 species defined by Kliment et al. (2007a) as differential

3 species defined by Kliment et al. (2007a) as constant

A species-poor (on average 12 higher taxa per relevé) tall-fern plant community. Owing to the thick layer of litter, consisting mostly of dense tangle of dead leaves of Alpine lady-fern (Athyrium distentifolium) from the previous year, the ground herb layer and cryptogam layer are strongly underdeveloped. The typical stands are on shaded and stabilised silicate screes of leeward slopes with ample snow accumulation in winter, which afterwards provides sufficient soil moisture. The phytocoenoses also occupy the canopy gaps in the dwarf pine shrubs, although they are gradually receding as a result of successive process of dwarf pine spreading. For more details see Krajčiová-Šibíková et al. (2005).

Delphinenion elati (Hadač ex Hadač et al. 1969) Boşcaiu et Mihăilescu 1997

Communities of tall broadleaved herbs in the montane to alpine belt on carbonates

Aconito firmi-Adenostyletum alliariae Domin 1930 nom. invers. propos.

Tab. 1, column 1

Diagnostic taxa: Adenostyles alliariae ${ }^{3}$, Alchemilla spec. div. $^{2}$, Chaerophyllum hirsutum ${ }^{3}$, Doronicum austriacum, Filipendula ulmaria, Milium effusum, Myosotis scorpioides agg., Saxifraga rotundifolia ${ }^{1}$, Senecio nemorensis agg. ${ }^{3}$, Silene dioica

Constant taxa: Acetosa arifolia ${ }^{3}$, Deschampsia cespitosa $a^{2}$, Geranium sylvaticum ${ }^{3}$, Geum rivale, Heracleum sphondylium, Hypericum maculatum ${ }^{3}$, Luzula sylvatica, Primula elatior ${ }^{3}$
Dominant taxa: Adenostyles alliariae, Alchemilla spec. div., Cortusa matthioli, Doronicum austriacum, Geranium sylvaticum, Luzula sylvatica

\footnotetext{
${ }^{1}$ species defined by Kliment et al. (2007a) as characteristic ${ }^{2}$ species defined by Kliment et al. (2007a) as differential

${ }^{3}$ species defined by Kliment et al. (2007a) as constant
}

A species-rich, floriferous, tall-herb plant community. The optimal biotope of these chionophilous phytocoenoses are stabilised calcareous screes with deeper soil and a sufficient amount of unrotted humus and organic matter. The typical stands are confined to steep, narrow and long, NW facing avalanche paths; moist, concave depressions on the lower parts of glens, or in the canopy gaps in the dwarf pine shrubs. The important ecological factor is the periodical torrential water during the rains and snow melting. The snow cover is quite deep and lasts up to late spring. For more details see Šibíková et al. (2008c).

\section{Geranio robertiani-Delphinietum elati Kliment et al. 2004}

\section{Dominant taxa: Delphinium elatum ${ }^{1}$}

One of the most beautiful, but also one of the most rare (with only two recent localities) plant communities of the class Mulgedio-Aconitetea in the Krivánska Malá Fatra Mts. The phytocoenoses occur on rocky calcareous screes at the bottom of moist, steep avalanche paths. The stands are protected by the rocky fences of cirques or by the dwarf pine shrubs on the side slopes of the glens. For more details and for the second recent relevé see Kliment et al. (2004).

\section{Relevé 1}

Locality: Krivánska Malá Fatra Mts, Mt. Velký Kriváň, eastern slope above the end of Révayovská dolina Valley; the edge of the avalanche glen within the dwarf pine stands, which divides the limestone and quartzite part of the mountain; the area of the relevé was disconnected in the middle by the depression dominated by Alchemilla sp.; $1495 \mathrm{~m}$ a. s. l.; $49^{\circ} 11^{\prime} 15,8^{\prime \prime} \mathrm{N} ; 19^{\circ} 02^{\prime} 10,8^{\prime \prime} \mathrm{E}$; aspect: $\mathrm{N}$, slope: $25^{\circ}$, geology: contact of quartzite scree with limestone, area: $18 \mathrm{~m}^{2}$ (comprises 2 close smaller areas), total cover: $100 \%$, cover $\mathrm{E}_{1}: 100 \%$, cover $\mathrm{E}_{0}: 55 \%$; date: 1. 8. 2003; authors: Šibíková \& Šibík.

$\mathbf{E}_{1}$ : Delphinium elatum ${ }^{1} 4$, Alchemilla sp. $2 \mathrm{~b}$, Festuca carpatica $2 \mathrm{~b}$, Geranium sylvaticum 2b, Hypericum maculatum $2 \mathrm{~b}$, Calamagrostis villosa 2a, Cortusa matthioli 2a, Heracleum sphondylium $^{2}$ 2a, Pimpinella major 2a, Primula elatior 2a, Saxifraga rotundifolia $2 \mathrm{a}$, Acetosa arifolia 1, Achillea ${ }^{*}$ alpestris 1, Astrantia major 1, Deschampsia cespitosa 1, Geum rivale 1, Rubus idaeus 1, Senecio hercynicus ${ }^{2} 1$, Aconitum * moravicum + , Adenostyles alliariae +, Athyrium distentifolium +, Bart- 
sia alpina + , Campanula serrata + , Cardaminopsis borbasii + , Carex sempervirens + , Chaerophyllum hirsutum ${ }^{2}+$, Crepis mollis +, Daphne mezereum +, Epilobium alpestre +, Galium anisophyllon + , Gentiana asclepiadea + , Knautia arvensis agg. + , Leontodon ${ }^{*}$ hispidus + , Leucanthemum margaritae + , Lotus corniculatus s. 1. + , Myosotis sylvatica + , Phyteuma orbiculare ,+ P. spicatum + , Poa alpina + , Potentilla aurea,+ P. crantzii + , Scabiosa lucida + , Senecio subalpinus + , Sesleria tatrae +, Silene vulgaris + , Solidago ${ }^{\star}$ minuta + , Trisetum flavescens + , Valeriana tripteris + , Viola biflora ${ }^{2}+$.

$\mathbf{E}_{0}$ : Leskea polycarpa 3, Tortula ruralis 1 , Schistidium apocarpum + , Ptychodium plicatum + .

${ }^{1}$ species defined by Kliment et al. (2007a) as characteristic ${ }^{2}$ species defined by Kliment et al. (2007a) as constant

\section{Petasito-Chaerophylletalia Morariu 1967}

Natural tall-herb nitrophilous riparian communities along rivers and streams in the submontane and montane (subalpine) belt

\section{Petasition officinalis Sillinger 1933}

Tall-herb broadleaved natural riparian communities on alluviums and banks of mountain streams in the Carpathian and Hercynian region

\section{Aconito firmi-Rumicetum alpini Unar in Unar et al. 1985}

Tab. 1, column 3

Diagnostic taxa: Rumex alpinus ${ }^{1}$

Constant taxa: Acetosa arifolia ${ }^{2}$, Aconitum *moravicum $^{2}$, Alchemilla spec. div. ${ }^{3}$, Athyrium distentifolium ${ }^{2}$, Deschampsia cespitosa ${ }^{2}$, Hypericum maculatum, Luzula * rubella

Dominant taxa: Rumex alpinus, Stellaria nemorum ${ }^{3}$

${ }^{1}$ species defined by Kliment et al. (2007a) as characteristic ${ }^{2}$ species defined by Kliment et al. (2007a) as differential

${ }^{3}$ species defined by Kliment et al. (2007a) as constant

A rare chionophilous, subhygrophilous to hygrophilous tall-herb plant community dominated by Rumex alpinus, which forms closed phytocoenoses on natural sites. The stands of the association occupy NW-SW facing, moist to wet concave slopes and glens with a high level of ground water or springs. For more details see Šibíková et al. (2007).

\section{ACKNOWLEDGEMENTS}

We are grateful to Dr. Z. Dúbravcová and to Dr. J. Kliment for the fieldwork collaboration, to Dr. K. Mišíková and Dr. R. Šoltés for determination of mosses, and to D. Treplanová for assignment of $\mathrm{pH}$ values. We are grateful also to the reviewers for their valuable comments and suggestions. This contribution was supported by the grant agency VEGA no. 6057.

\section{REFERENCES}

Barkman, J. J., Doing, H. \& Segal, S. 1964: Kritische Bemerkungen und Vorschläge zur quantitativen Vegetationsanalyse. Acta Botanica Neerlandica 13: 394-419.

Bělohlávková, R. 1980: Rostlinná spoločenstva alpínskeho stupně Kriváňské Malé Fatry. Mscr.

Bertová, L. (ed.) 1984: Flóra Slovenska 4/1. Veda, Bratislava, 432 pp.

Braun-Blanquet, J. 1930: Zentralalpen und Tatra, eine pflanzensoziologische Paralelle. Veröffentlichen des Geobotanischen Institutes Rübel 6: 81-123.

Braun-Blanquet, J. 1964: Pflanzensoziologie. Grundzüge der Vegetationskunde. ed. 3. Springer-Verlag, Wien, New York., 865 pp.

Chytrý, M., Tichý, M., Holt, J. \& Botta-Dukát, Z. 2002: Determination of diagnostic species with statistical fidelity measures. Journal of Vegetation Science 13: 79-90.

Chytrý, M. 2007: Vymezení vegetačních jednotek a jejich interpretace. Delimitation and interpretation of vegetation units. In: Chytrý, M. (ed.). Vegetace České republiky. 1. Travinná a keříčková vegetace. Academia, Praha, pp. 19-34

Dúbravcová, Z. \& Hajdúk, J. 1986: Príspevok k výskumu vegetácie subalpínskeho stupňa Sivého vrchu v Západných Tatrách. Zborn. Slov. Nár. Múz., Prír. Vedy, Bratislava, 32: 33-54.

Ellenberg, H., Weber, H. E., Düll, R., Wirth, W., Werner, W. \& Paulißen, D. 1992: Zeigerwerte von Pflanzen in Mitteleuropa. ed. 2. Scripta Geobotanica 18: 1-258.

Hadač, E., Březina, P., Ježek, V., Kubička, J., Hadačová, V., Vondráček, M. et al. 1969: Die Pflanzengesellschaften des Tales „Dolina Siedmich prameňov" in der Belauer Tatra. Vegetácia ČSSR, Ser. B, Bratislava, 2: 5-343.

Haško, J. \& Polák, M. 1980: Geologická mapa Kysuckých vrchov a Krivánskej Malej Fatry. Regionálne geologické mapy Slovenska. 1: 50 000. Geologický ústav Dionýza Štúra, Bratislava, 1 map.

Hennekens, S. M. \& Schaminée, J. H. J. 2001: TURBOVEG, a comprehensive data base management system for vegetation data. Journal of Vegetation Science 12: 589-591. 
Herben, T. \& Münzbergová, Z. 2003: Zpracování geobotanických dat v příkladech. Část 1. Data o druhovém složení. Praha, 118 pp. [http://botany.natur.cuni.cz/pdf/multivar.pdf]

Hill, M. O. 1973: Diversity and evenness: a unifying notation and its consequences. Ecology 54: 427-432.

Janík, M. 1971: Pastva na holiach krivánskej Malej Fatry a jej negatívny vplyv na krajinu. Životné prostredie 5: 69-75.

Karner, P. \& Mucina, L. 1993: Mulgedio-Aconitetea. In: Grabherr, G. \& Mucina, L. (eds). Die Pflanzengesellschaften Österreichs II, Gustav Fischer, Jena, p. 469-505.

Kliment, J. 1995: Digitali ambiguae-Calamagrostietum arundinaceae Sill. 1933 - eine Hochgras- oder Schlagflur-Gesellschaft? Preslia 67: 55-70.

Kliment, J. 1998: Porasty asociácie Senecioni fuchsiiCalamagrostietum arundinaceae (Sillinger 1933) Hadač in Mucina et Maglocký 1985 vo Velkej Fatre. Bull. Slov. Bot. Spoločn. 20: 159-165.

Kliment, J. 2004: Spoločenstvá zväzu Calamagrostion arundinaceae v Nízkych Tatrách. Príroda Nízkych Tatier 1: 137-146.

Kliment, J. \& Jarolímek, I. 1995: The Rumex alpinus communities in Slovakia. Biologia, (Bratislava) 50: 349-365.

Kliment, J. \& Jarolímek, I. 2003: Syntaxonomical revision of the plant communities dominated by Calamagrostis arundinacea (Calamagrostion arundinaceae) in Slovakia. Thaiszia-Journal of Botany 13: 135-158.

Kliment, J., Jarolímek, I., Šibík, J. \& Valachovič, M. 2004: Syntaxonomy and nomenclature of the communities of the orders Calamagrostietalia villosae and Adenostyletalia in Slovakia. ThaisziaJournal of Botany 14 (2): 93-157.

Kliment, J., Jarolímek, I. \& Šibík, J. 2007a: MulgedioAconitetea Hadač et Klika in Klika 1948. In Kliment, J. \& Valachovič, M. (eds). Rastlinné spoločenstvá Slovenska. 4. Vysokohorská vegetácia. Veda, Bratislava. pp. 21-129.

Kliment, J., Valachovič, M. (eds), Bernátová, D., Dúbravcová, Z., Jarolímek, I., Petrík, A., Šibík, J., Uhlírová, J. 2007b: Rastlinné spoločenstvá Slovenska. 4. Vysokohorská vegetácia. Veda, Bratislava, 388 pp.

Krajčiová-Šibíková, I., Šibík, J., Jarolímek, I. \& Mišíková, K. (2005): The association Adenostylo alliariae-Athyrietum alpestris (Zlatník 1928) Jeník 1961 in the Krivánska Fatra Mts. Bull. Slov. Bot. Spoločn. 27: 199-206

Lepš, J. \& Šmilauer, P. 2000: Mnohorozměrná ana- lýza ekologických dat. Biologická fakulta Jihočeské univerzity v Českých Budějovicích, České Budějovice, 102 pp. [http://regent.bf.jcu.cz/ skripta.pdf]

Ložek, V., 1972: Z historie přírody Malé Fatry. Ochrana Př́rody 9: 206-209.

Marhold, K. \& Hindák, F. (eds) 1998: Zoznam nižších a vyšších rastlín Slovenska. Veda, Bratislava, 687 pp.

McCune, B. \& Mefford, M. J. 1999: PC-ORD. Multivariate analysis of ecological data, version 4.0. MjM Software Design, Gleneden Beach, Oregon. 237 pp.

Pagáč, J. et al. 1983: Malá Fatra - Chránená krajinná oblas . Príroda, Bratislava, 356 pp.

Plesník, P. 1955: Vplyv pasenia na lesy Krivánskej Malej Fatry. Les 2 (1-2): 29-37.

Pott, R. 1995: Die Pflanzengesellschaften Deutschlands. Eugen Ulmer, Stuttgart, 427 pp.

Šibík, J., Valachovič, M. \& Kliment, J. 2005: Plant communities with Pinus mugo (alliance Pinion mugo) in the subalpine belt of the Western Carpathians - a numerical approach. Acta Soc. Bot. Pol., Wrocław, (74) 4: 329-343.

Šibíková, I. 2006: Vysokobylinné spoločenstvá (trieda Mulgedio-Aconitetea) v subalpínskom stupni Krivánskej Malej Fatry. M.Sc. Thesis, Faculty of Natural Sciences, Comenius University, Bratislava.

Šibíková, I., Šibík, J. \& Jarolímek, I. 2007: Zriedkavé rastlinné spoločenstvá triedy Mulgedio-Aconitetea v Krivánskej Malej Fatre. Bull. Slov. Bot. Spoločn., Bratislava, 29: 158-168.

Šibíková, I., Šibík, J. \& Jarolímek, I. 2008a: Plant communities of the alliance Calamagrostion arundinacea in the Krivánska Malá Fatra Mts. Thaiszia-Journal of Botany, submitted.

Šibíková, I., Šibík, J. \& Jarolímek, I. 2008b: Asociácia Festucetum carpaticae Domin 1925 v Krivánskej Malej Fatre. Zborn. Slov. Nár. Múz., Prír. Vedy, Bratislava, in press.

Šibíková, I., Šibík, J. \& Jarolímek, I. 2008c: Asociácia Aconito firmi-Adenostyletum alliariae Domin 1930 v Krivánskej Fatre. Bull. Slov. Bot. Spoločn. 30 (1): 69-88.

Šibíková, I., Šibík, J., Jarolímek, I. \& Kliment, J. 2009: Current knowledge and phytosociological data on the high-altitude vegetation in the Western Carpathians - a review. Biologia 64: in press.

ter Braak, C. J. F. \& Šmilauer, P. 2002: CANOCO reference manual and CanoDraw for Windows user's guide. Software for canonical community 
ordination (version 4.5). Biometris, Wageningen \& České Budějovice, 500 pp.

Theurillat, J.-P., Aeschimann, D., Kupfer, Ph. \& Spichiger, R. 1995: The higher vegetation units of the Alps. Colloques Phytosociologiques 23(1994): 189-239.

Tichý, L. 2002: JUICE, software for vegetation classification. Journal of Vegetation Science 13: 451-453.

Tichý, L. \& Chytrý, M. 2006: Statistical determination of diagnostic species for site group of unequal size. Journal of Vegetation Science 17: 809-818.

Tichý, L. \& Holt, J. 2006: JUICE, program for management, analysis and classification of ecological data. First part of the program manual. Veg- etation Science Group, Masaryk University Brno, 68 pp. [http://www.sci.muni.cz/botany/ juice/jc05_man.htm]

Valachovič, M. (ed.), O ahelová, H., Stanová, V. \& Maglocký, Š. 1995: Rastlinné spoločenstvá Slovenska. 1. Pionierska vegetácia. Veda, Bratislava, $185 \mathrm{pp}$.

Valachovič, M. (ed.), Háberová, I., Hájek, M., Hrivnák, R., Jarolímek, I., O ahelová, H, Šoltés, R. \& Záliberová, M. 2001: Rastlinné spoločenstvá Slovenska. 3. Vegetácia mokradí. Veda, Bratislava, $435 \mathrm{pp}$.

Westhoff, V. \& van den Maarel, E. 1978: The BraunBlanquet approach. In: Whittaker, R. H. (ed.). Classification of plant communities. W. Junk, The Hague, pp. 289-399. 
Table 1: Synoptic table of the tall-herb plant communities from the class Mulgedio-Aconitetea from the area of Krivánska Malá Fatra Mts. Diagnostic species $(\Phi \geq 0.300$; Fisher's exact test significance $\mathrm{p}<0.001)$ are ordered according to decreasing fidelity values (phi coefficient $\times 100$, upper index) and are regionally applicable. In the columns of the synoptic table with few relevés $(<5)$ the percentage of the frequency $(F)$ was replaced by the values of presence $(P)$ of individual taxa.

1 - Aconito firmi-Adenostyletum alliariae; 2 - Aconitetum firmi; 3 - Aconito firmi-Rumicetum alpini; 4 - Adenostylo alliariae-Athyrietum alpestris; 5 - Allio victorialis-Calamagrostietum villosae; 6 - Helianthemo grandifloraeCalamagrostietum arundinaceae; 7 - Potentillo aurei-Calamagrostietum arundinaceae; 8 - Festucetum carpaticae.

Tabela 1: Sinoptična tabela rastlinskih združb visokih steblik razreda Mulgedio-Aconitetea iz območja gorovja Krivánska Malá Fatra. Diagnostične vrste $(\Phi \geq 0.300$; Fisherjev test signifikantnosti $\mathrm{p}<0.001)$ so razvrščene po padajočih vrednostih navezanosti (fi koeficient $\times 100$, zgornji indeks) in so uporabne regionalno. V stoplcih sinoptične tabele $\mathrm{z}$ manj popisi $(<5)$ je odstotna frekvenca $(\mathrm{F})$ nadomeščena s prisotnostjo $(P)$ posameznih vrst. 1 - Aconito firmi-Adenostyletum alliariae; 2 - Aconitetum firmi; 3 - Aconito firmi-Rumicetum alpini; 4 - Adenostylo alliariae-Athyrietum alpestris; 5 - Allio victorialis-Calamagrostietum villosae; 6 - Helianthemo grandifloraeCalamagrostietum arundinaceae; 7 - Potentillo aurei-Calamagrostietum arundinaceae; 8 - Festucetum carpaticae.

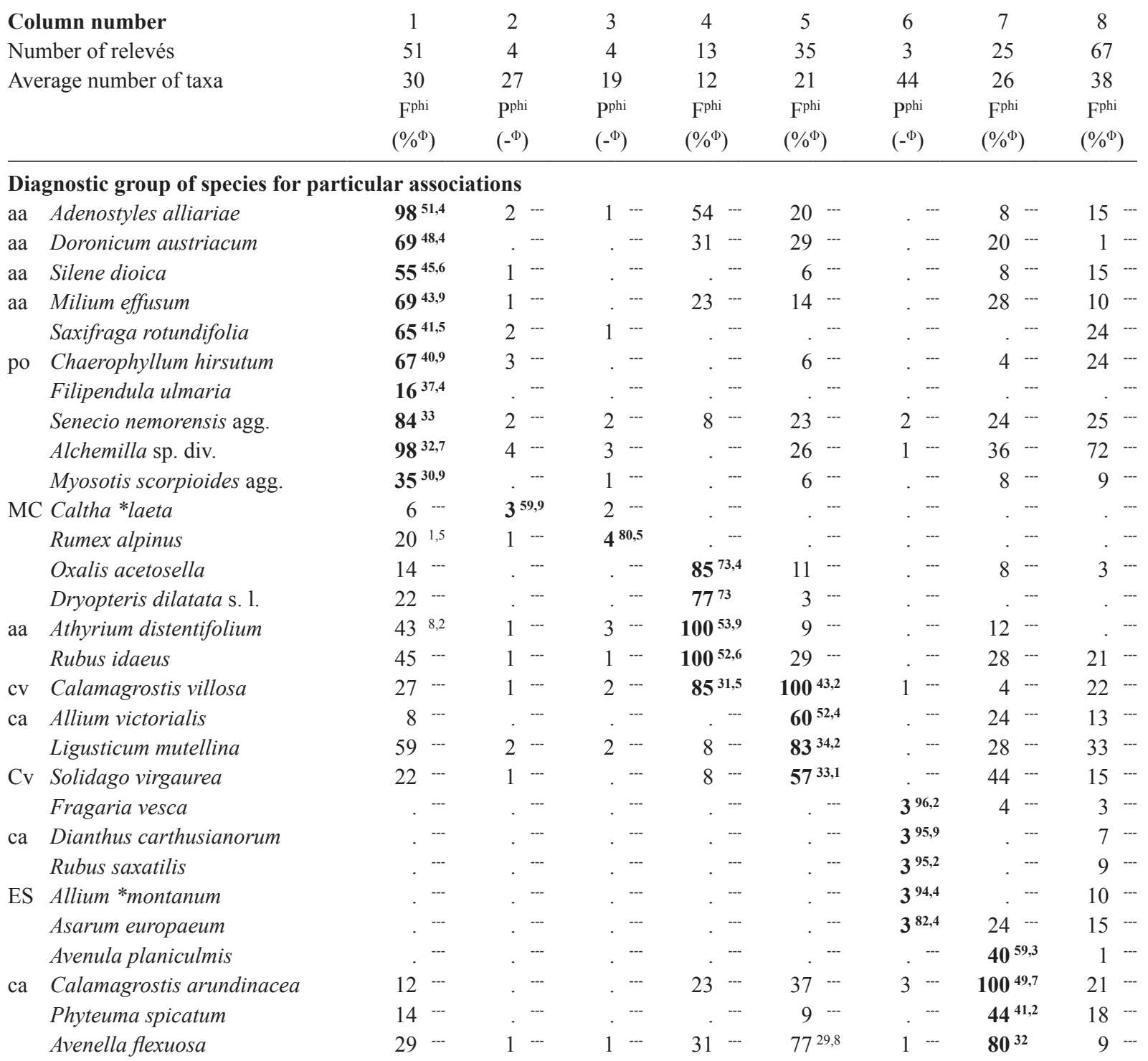




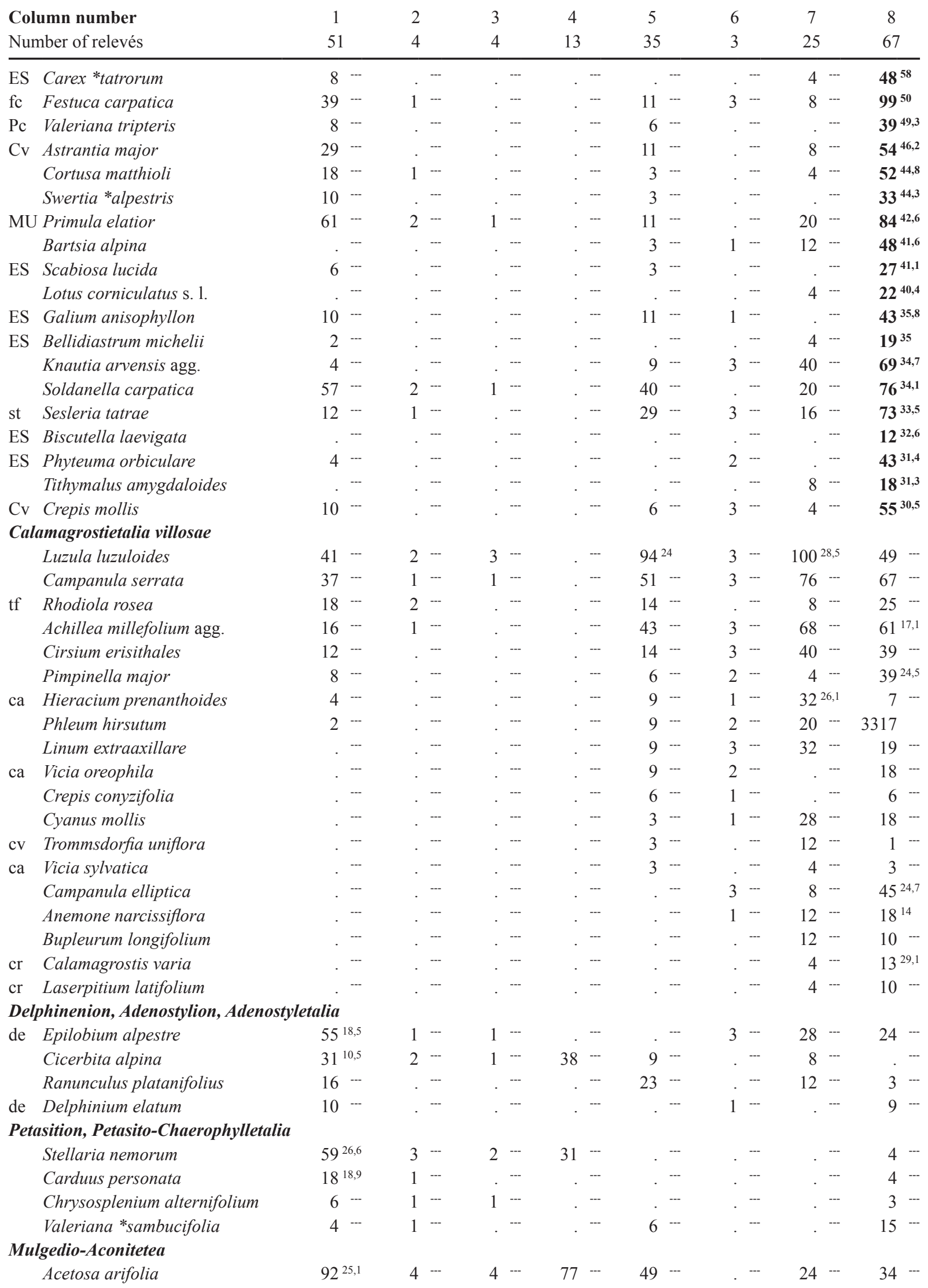


Column number

Number of relevés

5
86
5
5
5
5
3
3
6

1

$86 \ldots$

$57^{18}$

$57^{18}$

Senecio subalpinus

Aconitum *moravicum

Gentiana asclepiadea

Veratrum *lobelianum

Poa chaixii

Thalictrum aquilegiifolium

Aconitum variegatum

\section{Elyno-Seslerietea}

Ranunculus breyninus

Dianthus nitidus

Euphrasia salisburgensis

Thymus pulcherrimus

Carduus glaucinus

Helianthemum grandiflorum s. 1 .

Anthyllis *alpestris

Polygala *brachyptera

Gentianella fatrae

\section{Other species}

Hypericum maculatum

Deschampsia cespitosa

Geum rivale

Heracleum sphondylium

Luzula sylvatica

Viola biflora

Bistorta major

Homogyne alpina

LV Vaccinium myrtillus

MC Crepis paludosa

Trisetum flavescens

Epilobium montanum

Dactylis glomerata

NS Potentilla aurea

Cardaminopsis arenosa agg.

Urtica dioica

Dryopteris filix-mas

Myosotis sylvatica

MC Epilobium angustifolium

Vicia sepium

Ranunculus lanuginosus

Galium schultesii

Polygonatum verticillatum

ss Salix silesiaca

Adoxa moschatellina

NS Phleum rhaeticum

Symphytum tuberosum

Daphne mezereum

pt Delphinium oxysepalum

pm Pinus mugo

Picea abies

LV Vaccinium vitis-idaea

5

$39^{26}$

$37^{22,8}$

$6--$

2

$\begin{array}{ll}2 & 3 \\ 4 & 4\end{array}$

4
13

5

35

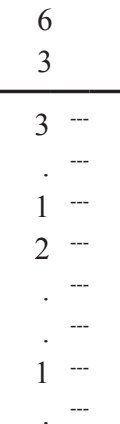

7
25

8

$4--$

$2--$

. -

69

15

9

$$
20-
$$

$51-$

66

$23-$

6

69

.--

$$
\begin{aligned}
& 6 \\
& 6-- \\
& \hline-- \\
& 3-
\end{aligned}
$$

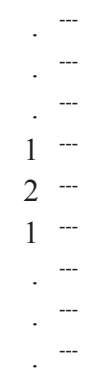

.

$19^{19}$

. $\cdot \cdot$

20

10

. - .

.--

6

$12--$

\begin{tabular}{|c|c|c|c|c|c|c|c|c|c|c|c|c|}
\hline 82 & 4 & 3 & --- & 15 & -- & 57 & -- & 1 & -- & 88 & --- & 78 \\
\hline $69^{17,1}$ & 4 & 4 & --- & & --- & 31 & -- & & -.- & 40 & --- & 28 \\
\hline $65^{21,5}$ & 4 & 1 & -- & & -- & 3 & -- & 1 & -- & 8 & -- & $64^{21}$ \\
\hline $65^{---}$ & 3 & 1 & -- & & -- & 29 & -- & 3 & -.- & 72 & -- & $75^{14,9}$ \\
\hline $65^{---}$ & 1 & . & -- & 15 & -- & 40 & -- & & -- & 32 & -- & 66 \\
\hline 43 & 3 & 2 & -- & 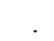 &.- & 37 & -- & 1 &.- & 12 & -- & $60^{16,2}$ \\
\hline $43^{---}$ & 2 & 2 & -- & . & -- & 43 & -- & 1 & -- & 28 & -- & 48 \\
\hline 41 & 2 & 2 & -- & 92 & -- & $77^{2}$ & & . & -- & 28 & -- & 46 \\
\hline $31--$ & 1 & 1 & -- & 85 & -- & $83^{2}$ & & . & -.- & 76 & -- & 49 \\
\hline $25^{---}$ & 3 & 1 & -- & . & -- & 11 & -- & 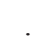 & -.- & & -- & 22 \\
\hline 25 & 2 & 1 & $\ldots$ & & -- & 6 & -- & 3 & -- & & -- & 31 \\
\hline 20 &. & 1 & -- & . & -- & 3 & -- & . & -- & . & -- & 6 \\
\hline 18 & 1 &. & --- & . & -- & . & -- & . & --. & 4 & --- & 19 \\
\hline 18 & 1 & 1 & --- & . & -- & 43 & -- & . & .-. & 48 & --- & 39 \\
\hline $18^{---}$ &. & 1 & --- & . & -- & & -- & 3 & -- & . & -- & $30^{7,6}$ \\
\hline $18^{27,8}$ &. &. & -- & 8 & -- & . & -- & . & -- & . & -- & 4 \\
\hline $16^{17,6}$ &. & 1 & -- & . & -- & r & -- & . & -- & . & -- & 1 \\
\hline $14^{---}$ & 1 & . & -- & . & -- & 3 & -- & 2 & --- & 24 & -- & 13 \\
\hline 14 &. &. & -- & 15 & -- & & -- & . & .-. & 16 & -- & 6 \\
\hline $14^{---}$ &. & . & -- & . & -- & 3 & -- & 1 & -- & 32 & -- & 13 \\
\hline 14 &. &. & -- & . & -- & 3 & $\ldots$ & . & -- & 8 & -- & 10 \\
\hline $14^{---}$ &. & . & -- & . & -- & . & -- & . & $\ldots$ & 12 & -- & 12 \\
\hline $12^{---}$ &. & . & --- & 8 & --- & 43 & -- & 1 & -- & 28 & -- & 36 \\
\hline $12^{---}$ &. & . & -- & . & -- & 17 & -- & . & -- & 24 & -- & 33 \\
\hline $10^{---}$ & 1 & . & -- & . & -- & . & -- & & --. & . & -- & 3 \\
\hline $10^{---}$ &. & 1 & -- & . & -- & . & -- & . & -- & . & -- & 1 \\
\hline $10^{---}$ &. & . & -- & & -- & . & -- & 1 & -- & . & -- & 18 \\
\hline $10^{---}$ &. & . & -- & & -- & . & -- & & -- & . & -- & 7 \\
\hline 10 &. & . & -- & & -- & & -- & & $\ldots$ & . & -- & 1 \\
\hline 2 & 1 & . & -- & 15 & -- & 11 & -- & & -- & 8 & -- & 16 \\
\hline -.- & $\ldots$ & . & -- & & --. & 23 & -.. & & --. & 8 & -- & 12 \\
\hline 2 &. & 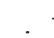 & -- & & -- & 23 & -- & & -- & 36 & -- & 13 \\
\hline
\end{tabular}

$25^{26,1}$

4 --

$3-$

$1-$ 
Column number

Number of relevés

1

2
4

Lilium martagon

Sorbus aucuparia

sa Sesleria albicans

Carlina acaulis

Leucanthemum vulgare agg.

Ranunculus nemorosus

Vicia cracca

Digitalis grandiflora

Pilosella aurantiaca

Ranunculus pseudomontanus

Thymus alpestris

Agrostis capillaris

Leontodon hispidus

Anthoxanthum alpinum

Stachys alpina

Hieracium lachenalii

Potentilla crantzii

Tragopogon orientalis

ss Lathyrus vernus

Botrychium lunaria

Paris quadrifolia

Mercurialis perennis

Parnassia palustris

cf Salix alpina

Myosotis alpestris

Athyrium filix-femina

Galeobdolon luteum s. 1.

AT Cystopteris fragilis

ar Arabis alpina

Acer pseudoplatanus

Poa alpina

Pc Asplenium viride

Streptopus amplexifolius

Rosa pendulina

Taraxacum sp.

Polystichum lonchitis

Festuca *versicolor

Campanula cochlearifolia

Coeloglossum viride

ar Cystopteris montana

Scrophularia scopolii

pt Saxifraga wahlenbergii

Sorbus aria agg.

Gymnocarpium dryopteris

Pedicularis verticillata

Petasites albus

Carex ovalis

Salix caprea

Cruciata glabra

Galium mollugo agg.

Poa nemoralis

6

8

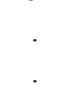$$
2
$$$$
2
$$$$
8
$$

$$
2
$$$$
2
$$

$$
2
$$

$$
6
$$$$
8
$$$$
\begin{aligned}
& 8 \\
& 6
\end{aligned}
$$

6
6

(6)

6

$$
\begin{aligned}
& 6 \\
& 6
\end{aligned}
$$$$
6
$$

(1)

$$
4
$$$$
4
$$

(4)

(1)

$$
2
$$

(1)

(1)

2

2

2

2
2
2
2

2

4

4
13

\begin{tabular}{|c|c|c|c|}
\hline$\ldots$ & $\ldots$ & $\ldots$ & $\ldots$ \\
\hline $8^{---}$ & -- & .-- & $8--$ \\
\hline-- & -- &.-- & --- \\
\hline-- & $-\cdots$ &.-- &.-- \\
\hline-- & -.- &.-- & -- \\
\hline 2 & --- &.-- & \\
\hline
\end{tabular}

\begin{tabular}{cc}
5 & 6 \\
35 & 3 \\
\hline
\end{tabular}

7

25

67

17

17

11

9

$3-$

$9-$

6

$3-$

$9-$

$3-$

. -

6

6

. -

.--

. -

6

$\cdot^{---}$

44

$33^{24,8}$

$12-\quad 7^{---}$

.-- 6 ---

.--

40

22

2

36

$34^{16,8}$

$19--$

2

28

13

28 --

9 --

2

24

20 --

1 -.-

16

10

$16-6-$

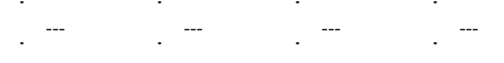

$\cdot+\cdot{ }^{--}+\cdots$$$
6
$$ 


\begin{tabular}{|c|c|c|c|c|c|c|c|c|c|c|}
\hline Column number & 1 & 2 & 3 & 4 & $\begin{array}{c}5 \\
25\end{array}$ & & 6 & $\begin{array}{c}7 \\
25\end{array}$ & 8 & \\
\hline Number of relevés & 51 & 4 & 4 & 13 & 35 & & 3 & 25 & 67 & \\
\hline Origanum vulgare & . --- &.$^{---}$ &.-- &.$^{---}$ & 3 & --- &.--- & $8^{--}$ & 6 & -- \\
\hline Thalictrum minus & . --- & . --- &.-- &.$^{---}$ & 3 & --- &.--- & $4--$ & 4 & -- \\
\hline Galium verum &.$^{---}$ & . --- & . --- &.-- & 3 & -- & . --- & $4--$ & 3 & -- \\
\hline Rhinanthus pulcher & . --- & . --- &.-- &.$^{---}$ & 3 & --- & . --- & . --- & 7 & -- \\
\hline Maianthemum bifolium &.$^{---}$ & . --- & . --- &.$^{---}$ & 3 & -- &.-- & . -- & 3 & -- \\
\hline Galeopsis speciosa & . --- & . --- &.-- &.$^{---}$ & 3 & --- &.--- &.--- & 1 & -- \\
\hline Carex flacca & . --- & . --- &.-- &.--- & . & --- & $2--$ & $. \quad--$ & 7 & -- \\
\hline Arabis hirsuta agg. &.$^{---}$ &.$^{---}$ &.--- &.$^{---}$ & . & -- & $2--$ & $. \quad--$ & 6 & -- \\
\hline Clinopodium vulgare & . --- & . --- &.-- &.--- & . & -- & $1--$ &.-- & 3 & -- \\
\hline Hippocrepis comosa & . --- & . --- & . --- & $. \quad--$ & . & -- & $1--$ &.--- & 1 & -- \\
\hline Pc Saxifraga paniculata &.-- & . -- & . --- &.--- & . & -- & $1--$ &.-- & 1 & -- \\
\hline Ranunculus acris & . --- & . --- & . --- & $. \quad--$ & . & -- &.-- & $4^{--}$ & 4 & -- \\
\hline Trifolium pratense & . --- &.$^{---}$ &.--- &.-- & . & --- &.--- & $4^{---}$ & 4 & -- \\
\hline Pedicularis hacquetii & . --- & . --- & . --- &.-- & . & -- & . --- & $4--$ & 3 & -- \\
\hline Viola canina & . --- & . --- &.--- &.$^{---}$ & . & --- & ${ }^{\cdot} \cdot--$ & $4--$ & 3 & -- \\
\hline Cirsium eriophorum & . --- & . --- &.-- &.$^{---}$ & . & --- &.$^{---}$ & $4^{--}$ & 1 & -- \\
\hline Phleum pratense & $\cdot{ }^{---}$ &.$^{---}$ & $\cdot \cdot--$ & $\cdot^{---}$ & . & -- & 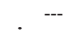 & $4--$ & 1 & -- \\
\hline
\end{tabular}

\section{Species found in one column:}

Column 1: Agrostis stolonifera 6, Cardamine flexuosa 2, Carex sylvatica 2, Epilobium collinum 4, Festuca rubra 2, Lamium maculatum 2, Lonicera nigra 2, Omalotheca norvegica 6, Ranunculus alpestris 2, Tussilago farfara 2, Valeriana officinalis 2.

Column 2: Festuca picturata 1, Poa pratensis 1.

Column 3: Epilobium roseum 1, Juncus filiformis 1.

Column 5: Hypochaeris radicata 6, Nardus stricta 3, Silene nemoralis 3.

Column 7: Fagus sylvatica 4, Libanotis pyrenaica 8, Omalotheca sylvaticum 4, Rhinanthus serotinus 8, Saxifraga aizoides 4, Silene *alba 4, Traunsteinera globosa 4 .

Column 8: Acetosa scutata 4, Aconitum vulparia 1, Aegopodium podagraria 1, Ajuga reptans 4, Anemone ranunculoides 1, Angelica archangelica 3, Angelica sylvestris 3, Aquilegia vulgaris 1, Bistorta vivipara 1, Brachypodium pinnatum 1, Brachypodium sylvaticum 4, Briza media 4, Carum carvi 1, Convallaria majalis 9, Festuca pratensis 1, Festuca supina 3, Festuca tatrae 3, Gentianella lutescens 1, Gymnadenia conopsea 4, Gymnocarpium robertianum 3, Hesperis *nivea 4, Hieracium bifidum 6, Hieracium stygium 1, Huperzia selago 1, Hypericum hirsutum 1, Isopyrum thalictroides 3, Jovibarba globifera 1, Laserpitium archangelica 1, Linum catharticum 4, Listera ovata 1, Prenanthes purpurea 1, Prunella vulgaris 1, Pulmonaria mollis 1, Pulmonaria obscura 3, Rhinanthus minor 1, Salix reticulata 1, Selaginella selaginoides 3, Silene vulgaris 9, Tofieldia calyculata 3, Veronica fruticans 1, Veronica chamaedrys 3, Vincetoxicum hirundinaria 1. 